Article

\title{
Exploring Twitter for CSR Disclosure: Influence of CEO and Firm Characteristics in Latin American Companies
}

\author{
Yuli Marcela Suárez-Rico ${ }^{1, *(\mathbb{C})}$, Mauricio Gómez-Villegas ${ }^{1(\mathbb{D})}$ and María Antonia García-Benau ${ }^{2}$ \\ 1 Escuela de Administración y Contaduría, Universidad Nacional de Colombia, Bogotá 111321, Colombia; \\ mgomezv@unal.edu.co \\ 2 Departamento de Contabilidad, Universidad de Valencia, 46022 Valencia, Spain; Maria.Garcia-Benau@uv.es \\ * Correspondence: ymsuarezr@unal.edu.co; Tel.: +34-612-462-897
}

Received: 30 June 2018; Accepted: 23 July 2018; Published: 26 July 2018

\begin{abstract}
Social networks, which are characterised by accessibility and interactivity, offer great potential for dialogue between companies and stakeholders, for example as platforms for publishing information on aspects of corporate social responsibility (CSR). In this paper, we use a synthetic index to analyse levels of CSR disclosure via Twitter, and identify explanatory variables of this disclosure by studying the demographic characteristics of the Chief Executive Officer (CEO) and of the company. This synthetic index was based on data for 93 companies located in the four countries of the Pacific Alliance (Chile, Colombia, Mexico, and Peru), using categories based on the 2016 Global Reporting Initave (GRI) Standards. The tweets were compiled during a period of two months in 2017, immediately before and after the publication of each CSR report. The synthetic index was taken as the dependent variable and used as the basis for multivariate regression analysis to identify the relationship between the level of CSR disclosure on Twitter and the characteristics of the firm and its CEO. The results obtained show that firms operating in environmentally-sensitive industries present higher levels of CSR disclosure on Twitter than those in other sectors. By country of origin, the Colombian and Chilean companies offered higher levels of disclosure than those in Mexico and Peru. The regression analysis revealed a positive relationship between the firm operating in a sensitive industry and its level of CSR disclosure on Twitter, and an inverse relationship between the latter variable and the tenure of the CEO.
\end{abstract}

Keywords: Twitter; CSR disclosure; legitimacy; upper echelons; CEO; firm

\section{Introduction}

Social networks have changed the way in which we inform and relate to each other. Web 2.0 has facilitated technological immersion in general, giving rise to phenomena such as the internet of things and web accountability, fostering real time interaction [1]. Among the most popular networks at this moment in time, Twitter is an interactive tool that allows users to inform each other and to take part in conversations in real time. Companies around the world are making use of this platform to increase their visibility and their proximity to stakeholders [2].

Recent studies of corporate social responsibility (CSR) have concluded that companies' use of social networks is a crucial factor in establishing engagement with stakeholders [3], and some researchers have highlighted large corporations' use of Twitter as a dialogical tool for transmitting information on CSR [4,5]. According to Merkl-Davis and Brennan [6], the use of social media is transforming the dynamics of accountability, and this change is especially apparent in areas such as CSR and sustainability, where larger numbers of stakeholders are involved. 
However, the studies which analyse the disclosure of CSR via Twitter are scarce. Recently, Dutot [7], Etter [5], and Chae [8] have indicated that philanthropic, labor and environmental issues are disclosed widely via Twitter. Nevertheless, the aforementioned studies have used subjective categories which could limit the scope of the analysis regarding the disclosure of CSR. To our knowledge, neither have any previous studies been conducted to examine the influence of corporate and CEO characteristics on the provision of CSR information through social networks, although some papers have acknowledged the strategic role played by new corporate media in areas such as the disclosure of CSR information [9-11].

In this field, most previous literature has analysed the disclosure of CSR information via traditional media, which is characterised by its one-way nature, from the organisation to its stakeholders [12-16]. Nevertheless, a few studies have recently considered the impact of two-way media, an area that includes social networks. These analysis are mainly descriptive, focusing on the degree of interaction of CSR messages on Twitter and Facebook, and tangentially exploring some categories of CSR disclosed by large corporations, mostly located in the Anglo-American environment, with the USA being the country which has had a wider coverage on this topic [4,5,17-20]. In the present study, we include social media in our analysis of CSR disclosure by companies operating in Pacific Alliance countries (Chile, Colombia, Mexico, and Peru), a regional grouping that has promoted the development of an internet revolution and a generation of initiatives oriented towards the promotion of sustainability [21]. As a result, these countries are among the most active in social networks worldwide [22]. With this study, we want to delve deeper into the analysis of the disclosure via social media carried out by the companies in this region and compare if these patterns are similar or different to the practices carried out by companies in developed countries, taking into account that various characteristics of the companies which have been studied in previous research differ ostensibly (due to their size and the amount of listed companies) in comparison to the companies of our sample.

Social networks differ from traditional communication media in the immediacy of the information supplied and in the possibilities for interaction that are offered to stakeholders. Accordingly, there is a need for more detailed analysis of the level of voluntary disclosure being achieved by companies using this platform. A novel aspect of the present study is that it incorporates the construction of a synthetic index of disclosure, based on objective categories taken from the 2016 GRI Standards. By these means, levels of transparency in different CSR dimensions can be evaluated, thus enabling companies to compare their performance in this field with that of their competitors, and to undertake new disclosure practices to bring them closer to their stakeholders.

Furthermore, taking into account that according to the legitimacy theory certain characteristics of the firm may influence voluntary disclosure, this study examines whether factors such as the firm's size or its operating within an environmentally-sensitive sector may have a positive impact on its level of CSR disclosure via Twitter. Moreover, in view of the fact that CSR disclosure and companies' use of social networks are both considered of strategic importance [23-26], we re-examine the 'upper echelons' theory with respect to the influence of CEO characteristics on CSR disclosure through Twitter.

In summary, this study has two main aims: to analyse the level of CSR disclosure via Twitter, doing so by means of a synthetic index based on the 2016 GRI Standards; and to identify explanatory variables of levels of disclosure according to the CEO and company characteristics.

This paper consists of six sections, including the present introduction. In the Section 2, we present our review of previous literature in this field and contextualise Twitter as an innovative tool of communication. Section 3 then presents the research design, describes how the study sample was determined and obtained, how the index was constructed, and how the regression model was applied. In the Section 4, the results of research are presented and, in the Section 5, a discussion is developed. Finally, we present the main conclusions drawn. 


\section{Literature Review and Exposition of Hypotheses}

\subsection{Legitimacy Theory}

The voluntary nature of CSR information disclosure encourages the use of new communication tools through which social and environmental aspects of company behaviour can be reported, in a way that is interactive and facilitates the governance of the organisation [6]. However, such disclosure may have associated costs derived from the exposition of company activity and strategy which can not only be seen by clients and stakeholders, but also by competitors, analysts, and creditors. Bachmann and Ingenhoff [27] and Benites-Lázaro and Mello-Théry [28], among others, have observed that some companies have a strong incentive to increase their disclosure of CSR actions in order to enhance the corporate image and thus acquire greater legitimacy. According to Suchman [29], legitimacy is the generalized perception that the acts performed are desirable, proper, or appropriate within a socially-constructed system of values, norms, and beliefs. This question is of particular interest to stakeholders, that is, those who may affect the organisation or be affected by it [30].

Accordingly, the legitimacy theory implies that this complies with a social assessment of acceptance and desirability, in which the assessment carried out by external spectators of both the organisation's activities and operations compliance with that which is socially accepted intervenes, which implies that legitimacy could be understood as a condition which reflects the social and cultural alignment of the organizations. Along the same lines Zimmerman and Zeitz [31] point out that legitimacy implies a correlation between organisation practices and declarations, and those which are withheld and approved by the social system. Due to this, legitimacy has been identified as a critical resource that the organizations have to maintain for their survival and growth.

Dowling and Pfeffer [32] suggest that any discrepancy between that which is expected by society and the declarations and activities presented by the organisation could generate threats to legitimacy which could take shape as economical, legal, or social sanctions. Taking into account that legitimacy is a social process, in which social values and circumstances evolve, the legitimacy theory allows the possibility to understand how organisations change and adapt their strategies as an answer to social expectations.

One of the ways in which the companies con build legitimacy is by means of CSR communication, showing how they identify with social values and their compliance with the standards set by the social system [31]. This implies that technological change is assumed to provide opportunities for companies to generate new forms of engagement with their stakeholders and to develop communication strategies that allow them to enhance their social acceptance. And one way to achieve this is by making use of Twitter [17].

Many researchers concur that large companies, due to their greater visibility, are subject to greater scrutiny and to pressure from governments and external stakeholders for them to behave in a socially responsible way $[15,33]$. Therefore, company size is assumed to be related to the level of CSR information disclosure [34-36].

According to prior research, companies that operate in business sectors that have a greater social and environmental impact have incentives to disclose more information about their CSR actions, as a legitimation strategy and a means of avoiding conflict with stakeholders [37]. Various empirical studies have concluded that when a company is active in an 'environmentally sensitive' sector, this circumstance is positively associated with the disclosure of social and environmental information [13,33,34]. According to Patten [15], Hackston and Milne [38], and Wang and Yao [39] Industrial, Mining, and Oil; and Electricity, Water, and Gas sectors are considered environmentally sensitive due to their impact on the environment.

Taking into account this information we put forth two hypotheses:

H1. There is a positive relation between the size of a firm and the level of CSR disclosure via Twitter.

H2. Belonging to a sensitive industry has a positive influence regarding the level of CSR disclosure via Twitter. 


\subsection{Upper Echelons Theory}

In another approach, the upper echelons theory suggests that senior executives can play a pivotal role in the processes and strategic practices employed by companies. In this respect, the $\mathrm{CEO}$ is directly related to the decision-making process that affects the performance and results of the entire organization. According to Astley and Van de Ven [40], CEOs are in a position to influence their companies' design, structure, and responses, shaping and imbuing them with a personal style. For Carpenter et al. [41], a companies' policy choice reflects the cognitive foundations of their CEO, which are a function of their observable characteristics. This is based on Hambrick and Mason's [42] approach, which indicates that the individual's psychological properties can be difficult to capture, thus the observable characteristics become a rational indicator of their cognitive foundations.

In view of these considerations, many of the studies that have considered the relationship between CEOs and their companies' strategic decisions have analysed the influence of observable demographic characteristics—-such as age, gender, and tenure-on organisational practices and culture and the interrelation between the institution and its environment [41,43], with tenure becoming one of the most interesting characteristics observed in previous studies [42,44]. Hambrick and Mason [42] also take into consideration educational background, but they admit that this type of variable can be a blurry indicator of socioeconomic background, cognitive styles, propensity to risk, among others.

Among the intangible strategic decisions, we could take into account those related with CSR which-since they are related with socially desirable aspects—can bring advantages both for the organisation as well as its CEO, in relation to reputation, employee support, and appeal to responsible consumers [45]. Taking into account that CSR communication via new media like Twitter is strategic due to the fact that it allows establishing relations with stakeholders and obtaining feedback by means of their opinions, it is expected that the CEO's characteristics will have a direct influence on the level of CSR disclosure accomplished via these means. However, despite the strategic importance of CSR to many organisations, very few studies have addressed the question of the role played by the CEO in the dissemination of information on CSR [46,47]. Previous studies have been based mainly on characteristics like age, see for example [48]; experience and tenure, see for example [46,49]; and gender, see for example $[49,50]$ as decisive regarding CSR, but none have analysed their disclosure via social media.

Regarding demographic characteristics, the gender of the CEO has been less studied than that of board members, with respect to CSR. In this field, Manner [49] reported that the gender of the CEO is positively associated with CSR reporting, in contrast to Huang [51], who found such influence to be weak compared to other characteristics such as the CEO's level of education. In what concerns attitudes towards innovation, Zhang et al. [52] found no significant influence of gender on the culture of innovation or on its implementation.

With regard to the organization's disclosure of social and environmental information, empirical studies have shown that when the company board has a higher proportion of female members, there tends to be more corporate transparency [50].

Studies have shown that age is one of the demographic factors which has most impact on attitudes towards innovation and the establishment of new strategies involving organisational change. Thus, younger CEOs are more likely to intensify the use of technology in the organisation, to try new tools, to pioneer new organisational practices and to incorporate new ideas and tendencies in their decision making [53-55]. Moreover, it has been argued that the CEO's age and career horizon are directly related to CSR commitment [48], with older CEOs presenting less commitment in this respect as the horizon of their professional career approaches.

Tenure is another relevant factor. In other words, the CEO's length of service within a given organisation is directly related to the strategic decisions taken and to the application of innovative tools [56]. With respect to organisational strategies, research has highlighted the existence of an inverse relationship between tenure and the likelihood of organisational change [57]. In consequence, executives who have occupied their position for a shorter time are more inclined to experiment and 
to pursue innovative strategies, while those with more experience in the organisation are usually more resistant to change [46]. The disclosure of CSR information via social networks represents a considerable and innovative change in the pattern of external communication because it extends visibility and the impact of the information, as well as allowing the participation and creation of contents by the stakeholders for most companies; we would expect CEOs with less tenure to be more likely to disclose CSR information via this medium, viewing it as a strategic opportunity to reach a larger audience and improve their reputation. On the other hand, those CEOs with a longer tenure could perceive CSR disclosure via Twitter as a risk and may prefer to promote communication by means of traditional media which they have already worked with, and the results of which they know better.

Taking into account this information we put forth three hypotheses:

H3. The CEO's gender has a positive effect on the disclosure of CSR via Twitter.

H4. The age of the CEO has a negative effect on the level of disclosure of CSR via Twitter.

H5. The CEO's tenure has a negative influence on the level of disclosure of CSR via Twitter.

Figure 1 shows a graphic relation between the characteristics of the firm, the CEO and the hypothesis.

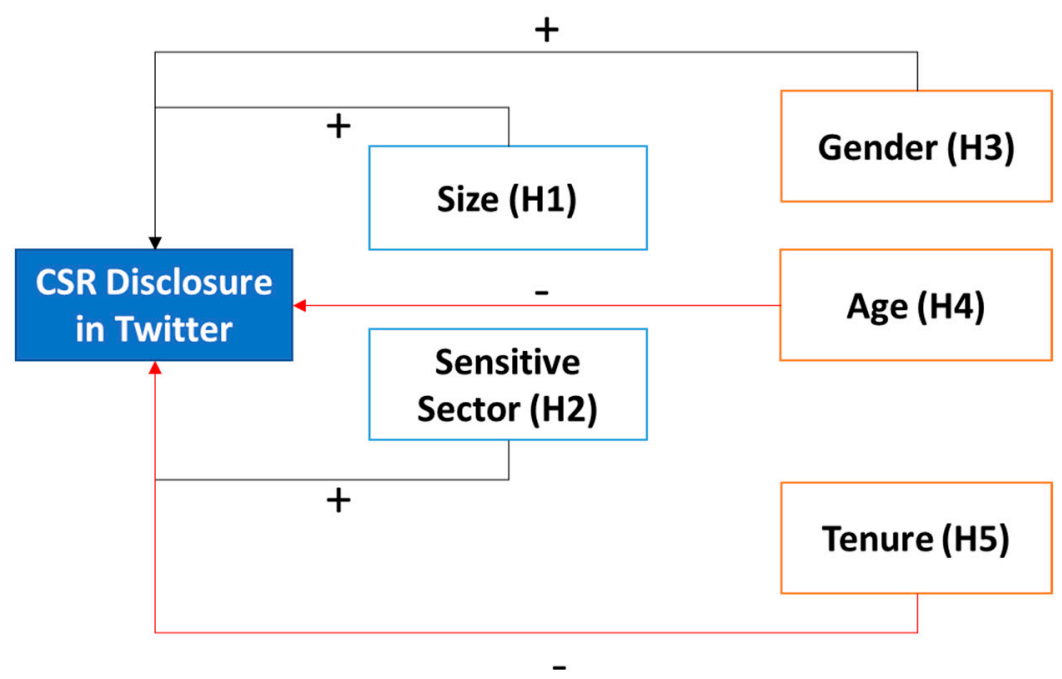

Figure 1. This figure shows the relation between the firm's characteristics (Size and Sensitive Sector) and the CEO's characteristics (Gender, Age, and Tenure) in relation with the level of corporate social responsibility (CSR) disclosure via Twitter. For Size, Sensitive Sector, and Gender we expect a positive influence, while Age and Tenure should have a negative influence.

\subsection{Twitter as an Innovatory Medium of Communication}

Since its inception, the internet has fostered information disclosure and facilitated communication. Its evolution to what is now known as web 2.0 has led to the generation of large volumes of data, combining text, images, video, and conversations in multiple applications and contents [1].

One of the main characteristics of web 2.0 is its social nature. Thus, it is widely considered a socio-technological system that promotes interaction, cognition, and communication [58]. For this purpose, social networks allow users to create profiles and share images, texts, videos, and links to web pages, in many cases seeking thereby to build relationships [59].

The dynamics of offering and/or receiving information through social networks responds to an innate need for communication, taking the form of disclosure in which each actor freely chooses what to disclose and how to do so [60]. This is why Twitter has become such a popular social medium among users and corporations worldwide [61]. The platform currently has over 330 million monthly 
users, transmits more than 500 million messages each day, and has in excess of 60 million users in Latin America alone. As an example of its popularity in this continent, Mexico has the third largest number of users outside the United States [62,63].

One of the factors which has made it easier to use Twitter for CSR communication, is the perception of democratic participation linked to larger possibilities of social activism, digital citizenship and free discourse which had not been possible by means of one-way media [64], due to the greater accessibility, which generates a larger demand for information, leading to the creation of a social media practice in which stakeholders interact with companies on matters that affect them $[65,66]$, achieving results that cannot be readily obtained via traditional means of communication, which are viewed as both expensive and static [67].

Studies have reported that many companies now construct long-term relationships with their stakeholders and increase positive perceptions in society through Twitter, which facilitates the dissemination of relevant information in a user-friendly format $[3,60,68]$. Chae and Park [8] suggest that the communication of CSR via Twitter presents different dynamics to that of traditional media due to the type of participants and the interaction which is possible via this platform. This implies that communication is less formal but has a higher visibility and emotional impact to users. According to Araujo and Kollat [69], effective communication of CSR via Twitter can influence the social evaluation of an organisation, improving the identification that stakeholders have with a company and, as a consequence, generating a better corporate reputation as a long term effect.

\section{Study Design}

\subsection{Sample}

For this study, the sample considered was composed of 93 companies, all located in countries belonging to the Pacific Alliance (Chile, Colombia, Mexico and Peru). The economic and commercial integration of this bloc has made it the world's eighth largest economy by GDP and has facilitated its adhesion to initiatives aimed at boosting competitiveness through innovations in sustainability [60]. Accordingly, the first step in our study design was to consider the 400 Pacific Alliance companies listed in the MERCO 2016 ranking of corporate social responsibility, which is an evaluation instrument in regard to CSR, with a multi-stakeholder methodology composed of five different evaluations and 12 sources of evaluation-among which we will find senior managers, financial analysts, NGOs, experts on CSR, social media, managers and journalists—which uses a public independent methodology [70]. This ranking was chosen due to the fact that it was the first audited worldwide based on the ISAE 3000 monitoring and verification process, and because it has been used as a sample for previous CSR studies like those carried out by Cegarra-Navarro and Martínez-Martínez [71], Ros-Diego and Castelló-Martínez [72], and Odriozola and Baraibar-Diez [73].

From these companies, we then selected those which had presented CSR information for 2016 and that had an official corporate Twitter account. Searches were conducted for these Twitter accounts on the company websites or directly on the Twitter website. Only accounts managed directly by these companies were considered. The search for information of the sample companies was carried out between December 2017 and March 2018. Finally, we eliminated those companies which did not have all the information available.

A period of two months was allocated for compiling this social network information for each company, as follows: one month prior to the publication of the 2016 CSR report (published in 2017) on the GRI website (www.globalreporting.org/standards), or on the respective stock exchange in the case of listed companies; and one month after this publication. In total, 1675 CSR-related tweets were compiled. The majority of CSR reports of the sample companies were released between the months of May, June, and July 2017, as a consequence the majority of tweets analysed were published between the months of April and August 2017. 
The final distribution of the companies, by country and by business sector, is shown in Table 1 , panels $\mathrm{A}$ and $\mathrm{B}$.

Table 1. Distribution of the sample.

\begin{tabular}{|c|c|c|c|}
\hline \multicolumn{4}{|c|}{ Panel A: Distribution by Country } \\
\hline Country & Freq. & Percent & Cum. \\
\hline Chile & 28 & 30.10 & 30.10 \\
\hline Colombia & 34 & 36.55 & 66.66 \\
\hline Mexico & 20 & 21.50 & 88.17 \\
\hline Peru & 11 & 11.82 & 100 \\
\hline Total & 93 & 100 & \\
\hline \multicolumn{4}{|c|}{ Panel B: Distribution by Sector } \\
\hline Sector & Freq. & Percent & Cum. \\
\hline Food and drink & 13 & 13.98 & 14.44 \\
\hline Cement & 4 & 4.30 & 18.28 \\
\hline Construction & 2 & 2.15 & 20.43 \\
\hline Energy, gas \& water & 8 & 8.60 & 29.03 \\
\hline Financial & 21 & 22.58 & 51.61 \\
\hline Business holding & 4 & 4.30 & 55.91 \\
\hline Industrial & 7 & 7.53 & 63.44 \\
\hline Mining & 7 & 7.53 & 70.97 \\
\hline Oil and hydrocarbons & 5 & 5.38 & 76.34 \\
\hline Retail & 6 & 6.45 & 82.80 \\
\hline Health & 5 & 5.38 & 88.17 \\
\hline Telecommunications & 8 & 8.60 & 96.77 \\
\hline Transport & 3 & 3.23 & 100 \\
\hline Total & 93 & 100 & \\
\hline
\end{tabular}

\subsection{Study Method}

The CSR tweets for this study were obtained by performing a manual content analysis based on the categories included in the GRI Standards [74]. Following Krippendorff [75], the contents analysis was carried out in stages. First we chose as analytical unit the tweet generated by the sample company-we did not include retweets or other contents generated by other Twitter accounts. In the case of tweets which included links or videos, these were viewed and their contents analysed. The following phase consisted in a first codification which reduced the tweets sample. To do so, each tweet was assigned a value of 1 if its content was related to CSR and 0 otherwise. The inclusion rules used were defined by reference to the categories of the GRI 2016 guidelines. To avoid intercoding problems, this process was conducted by a single researcher, the results were evaluated and discussed by other researchers, to gain consistency and solve interpretation differences. Afterwards, the categorization process with which the index was built was carried out taking into account only those tweets which were related to CSR.

\subsection{The Disclosure Index}

To measure the level of CSR disclosure on Twitter, we created a synthetic index composed of six sub-indexes corresponding to the disclosure categories of the 2016 GRI Standards: (1) General disclosure (GD), (2) Economic (Eco), (3) Environmental (Amb), (4) Employment (Empt), (5) Social (Soc), and (6) Product liability (Prod). In all cases, the sub-indexes are based on the presence or absence of categories, such that each category takes the score of 1 if the company tweets information in this respect and 0 otherwise. 
The total disclosure index (TDI) is defined as follows:

$$
\mathrm{TDI}=\mathrm{GD}+\mathrm{Eco}+\mathrm{Amb}+\mathrm{Lab}+\mathrm{Soc}+\text { Prod }
$$

The full index is composed of 39 categories divided into six sub-indexes. The GD index is composed of six categories that address aspects disclosed by the organisation, providing a view of its ethical and strategic outlook. These categories are detailed in Appendix A.

The economic disclosure index is based on the content of GRI Series 200, and consists of six categories that address aspects related to the organisation's direct and indirect economic impacts on its stakeholders.

The environmental disclosure index is based on the content of GRI Series 300, and refers to the focus and impact of the policies of the organisation (and its supply chain) on water, air, and biodiversity. This sub-index has eight categories.

The employment, social, and product liability disclosure indexes are based on GRI Series 400 and have seven, eight, and four categories, respectively. These sub-indexes reflect aspects of the organisation's approach to employment, the community, respect for human rights, and consumer protection through its products and services.

In line with Travassos-Conde [76], each sub-index was calculated as follows:

$$
\mathrm{Sub}-\operatorname{index}(\mathrm{Sb})=\frac{\mathrm{Sub}-\text { index score }}{\text { Maximum score possible }} \times 10
$$

\subsection{Regression Model}

In this study, the variables of interest are Size and IndSens as corporate features, and Gen, Age, and Tenure as demographic characteristics of the CEO. Additionally, we controlled by considering CEODuality, CSRComm, and Adherence. To test hypotheses H1 to H5, we propose the following model:

$$
\mathrm{TDI}=\beta 0+\beta 1 \text { Size }+\beta 2 \text { Indsens }+\beta 3 \text { Gen }+\beta 4 \text { Age }+\beta 5 \text { Tenure }+\beta 6 \text { CEODuality }+\beta 7 \text { CSRComm }+\beta 8 \text { Adherence }+\varepsilon
$$

where:

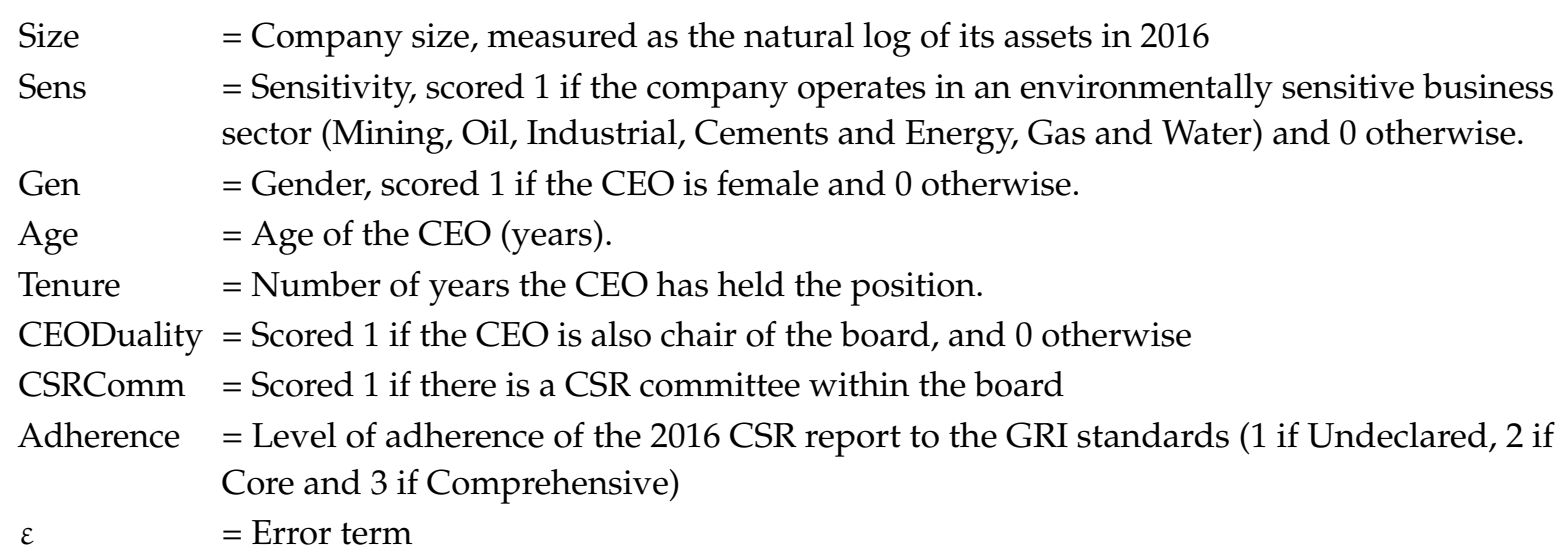

\section{Results}

\subsection{Descriptive Results}

A total of 1675 tweets on CSR-related topics were obtained, equivalent to $21.25 \%$ of all tweets issued by these companies during the study period. This percentage is slightly higher than that reported by Etter [4], for companies listed in the 100 Best Corporate Citizens for 2010. The business 
sectors of mining, energy, gas \& water, and food \& drink reported most CSR tweets in 2016, while the companies in the construction sector reported the fewest (see Table 2).

The most commonly-posted category on Twitter was that of Community, with 600 tweets; followed by Strategy, with 155; and Profile, with 134. These findings suggest that Twitter is being used as a means of legitimising the company to its stakeholders. It is significant that the above categories are ranked even higher than the environmental categories.

Table 2. CSR-related tweets, by business sector.

\begin{tabular}{llll}
\hline Sector & CSR Tweets & Percentage & Acc. \\
\hline Food and drink & 244 & $14.57 \%$ & $14.57 \%$ \\
Cement & 113 & $6.75 \%$ & $21.31 \%$ \\
Construction & 5 & $0.30 \%$ & $21.61 \%$ \\
Energy, gas \& water & 289 & $17.25 \%$ & $38.87 \%$ \\
Financial & 167 & $9.97 \%$ & $48.84 \%$ \\
Business holding & 51 & $3.04 \%$ & $51.88 \%$ \\
Industrial & 52 & $3.10 \%$ & $54.99 \%$ \\
Mining & 297 & $17.73 \%$ & $72.72 \%$ \\
Oil and hydrocarbons & 165 & $9.85 \%$ & $82.57 \%$ \\
Retail & 82 & $4.90 \%$ & $87.46 \%$ \\
Health & 81 & $4.84 \%$ & $92.30 \%$ \\
Telecommunications & 82 & $4.90 \%$ & $97.19 \%$ \\
Transport & 47 & $2.81 \%$ & $100.00 \%$ \\
\hline Total & 1675 & 100 & \\
\hline
\end{tabular}

The categories with less disclosure were those related with the product Responsibility index and the Human Rights category. This result is similar to that obtained in the study by Chae and Park [8] which indicated a decreasing tendency to cover these topics, in contraposition to those related with community support or environmental issues.

Regarding the level of information disclosure, the Colombian and Mexican companies presented the highest average TDI, while those from Chile had the lowest level of transparency in CSR-related topics published on Twitter, followed by Peru. Table 3 shows the descriptive statistics for each of the sub-indexes, with the general descriptive statistics in panel A, and the country-level statistics in panel B.

Table 3. Descriptive statistics—general and by country.

\begin{tabular}{ccccccc}
\hline Country & N & Mean & Median & sd & Min & Max \\
\hline Overall & 93 & 8.305 & 6.25 & 6.612 & 0 & 29.7 \\
Chile & 28 & 8.923 & 6.31 & 7.79 & 0 & 29.7 \\
Colombia & 34 & 9.055 & 6.34 & 6.591 & 1.25 & 24.05 \\
Mexico & 20 & 7.146 & 6.55 & 5.614 & 0 & 20.12 \\
Peru & 11 & 6.521 & 4.58 & 5.098 & 1.25 & 15 \\
\hline
\end{tabular}

The overall TDI obtained shows that the companies in our sample, in general, present a low level of CSR-related disclosure on Twitter, taking into account that the maximum score possible was 60 points. The average disclosure score was 8.31 and the maximum disclosure level was 27.9 , in the case of Chilean companies. By country the companies from Colombia had the highest average disclosure, followed by Chilean companies, while those from Peru had the lowest level of disclosure, with an average score of 6.52 .

By industry, Figure 2 shows that the Mining, Petroleum, and Cement industries produced the highest TDI scores, while the companies in the construction and industrial sectors produced the lowest levels of information disclosure in this respect. Environmentally sensible companies report a 
larger amount of tweets in the environmental category than their counterparts, while companies with low environmental sensibility report a larger amount of tweets in the society category. This follows the line of what was indicated by Cowen et al. [33] and Hackston and Milne [38], which indicated that environmentally sensible companies, like the extraction industry, were more prone to disclose environmental information than companies belonging to other industries, while those which are more consumer oriented tend to show a higher degree of concern towards the community to strengthen their corporate image and increase their sales.

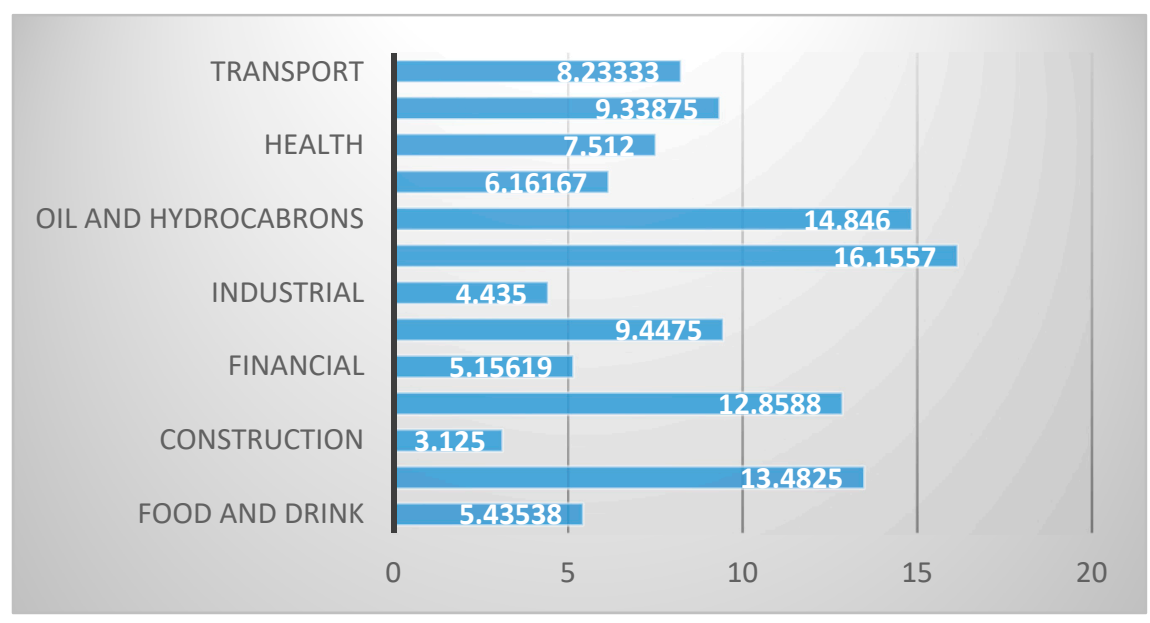

Figure 2. Total disclosure index, by business sector.

The company that achieved the highest TDI result in our sample was Codelco de Chile, in the mining sector, with a score of 29.7. This company also published the highest number of tweets related to the Economic sub-index. In the oil and hydrocarbons sector, the company Equión Energía obtained a score of 24.05 and published the highest number of tweets in the Social sub-index.

\subsection{Results of the Regression Analysis}

Table 4 shows the descriptive statistics obtained with the regression model for each of the study variables. The financial information was obtained from Orbis, and that for the CEO and the control variables was obtained manually from the respective company websites, the social network LinkedIn, and the companies' annual reports. With respect to the demographic characteristics of the CEOs in the sample, $96.12 \%$ were male. The average age of these CEOs was 53 years, with a range from 38 to 75 years. Regarding tenure, the CEOs of the companies analysed had held the position for an average of 6.02 years, but this period ranged from 0 to 36 years.

Table 4. Descriptive statistics of the variables.

\begin{tabular}{ccccccc}
\hline Variable & N & Mean & Median & sd & Min & Max \\
\hline Size & 93 & 15.17 & 15.01 & 1.70 & 9.66 & 18.01 \\
Sens & 93 & 0.24 & 0 & 0.43 & 0 & 1 \\
Gen & 93 & 0.07 & 0 & 0.25 & 0 & 1 \\
Age & 93 & 52.58 & 51 & 7.13 & 38 & 75 \\
Tenure & 93 & 6.02 & 4 & 7.60 & 0 & 36 \\
CEODuality & 93 & 0.38 & 0 & 0.49 & 0 & 1 \\
CSRComm & 93 & 0.26 & 0 & 0.44 & 0 & 1 \\
Adherence & 93 & 2.02 & 2 & 0.61 & 1 & 3 \\
\hline
\end{tabular}

The following firm characteristics were recorded: company size, average value 15.17, with a minimum of 9.66 and a maximum of 18.01 (calculated from the natural logarithm of total assets, 
to eliminate outliers). Of the companies in the sample, $35.92 \%$ operated in a business sector classified as sensitive.

Table 5 shows the results of the multivariate regression by OLS, performed using Stata 12 software. The $\mathrm{R}^{2}$ value indicates adequate goodness of fit. As well as the regression analysis, we also calculated the variance inflation factor (VIF). Previous studies have suggested that a VIF value $>10$ indicates the presence of multicollinearity. In our case, the VIF results obtained were $<2$, which indicates the absence of multicollinearity. White's correction was used to calculate robust estimators of heteroscedasticity, using the robust command.

The results obtained are indicative of an association between the characteristics of the CEO, those of the firm and its level of CSR disclosure on Twitter. In particular, the regression findings revealed a significant inverse association between tenure and the level of CSR disclosure on Twitter; thus, the longer the CEO's tenure, the lower the level of disclosure. This result is consistent with the conclusions reached by Finkelstein et al. [57] and Lewis et al. [46], according to whom CEOs with more years of permanence in their position tend to be less innovative and, perhaps, more resistant to change, which would go make them less inclined to disclose CSR information via new media such as Twitter. These results also corroborate those obtained by Oh et al. [48] regarding the fact that a CEO's professional horizon has a direct effect strategic corporate decisions, especially those which imply actions that extend over a long term and that involve changes which could imply risks. Thus CEOs with a shorter carrier horizon will incur in less CSR actions-orientated towards building long term relations with the stakeholders - as well as seeing the adoption of Twitter as a tool with larger risk and scrutiny. Given these results we accept hypothesis H5.

Table 5. Multivariate regression results.

\begin{tabular}{|c|c|c|c|c|c|}
\hline TDI & Coef. & Std. Err. & $t$ & $p>t$ & Significance \\
\hline Size & -0.31 & 0.35 & -0.89 & 0.375 & \\
\hline Sens & 3.69 & 1.82 & 2.02 & 0.047 & $* *$ \\
\hline Gen & -0.58 & 3.31 & -0.17 & 0.862 & \\
\hline Age & 0.14 & 0.09 & 1.46 & 0.147 & \\
\hline Tenure & -0.21 & 0.07 & -2.8 & 0.006 & $* * *$ \\
\hline CEODuality & 0.08 & 1.19 & 0.07 & 0.948 & \\
\hline CSRcommitee & 1.23 & 1.65 & 0.75 & 0.456 & \\
\hline Adherence & 2.93 & 0.97 & 3.02 & 0.003 & $* * *$ \\
\hline
\end{tabular}

Neither the gender nor the age of the CEO were found to influence the level of CSR disclosure on Twitter, which corroborates the previous findings of Zhang et al. [52]. Regarding the first of these questions, Correa et al. [77] observed that men and women make the same use of social networks such as Twitter, which could imply that both genders promote its use in the same way. As concerns the use of Twitter as a means of corporate communication, Wamba and Carter [78] found that the CEO's gender had no significant influence, due to this hypothesis $\mathrm{H} 3$ and $\mathrm{H} 4$ could not be corroborated.

Among the firm characteristics analysed, the results suggest that operating in a sensitive business sector has a significant positive influence on the level of CSR disclosure on Twitter, which is in line with the findings of Brammer and Millington [79] and Patten [15] and with the legitimacy theory. These results are also corroborated by means of the descriptive analysis which reflects that companies in the Mining, Oil, and Cement sectors are those that reach the highest levels of disclosure. It is notable that the Mining companies in the sample have experience reputation crisis in their areas of influence as a product of the pollution generated by their operations. For example, in the year 2016 the Chilean mining company Codelco experienced two concentrated copper spills in the Andes, generating both legal and social sanctions $[80,81]$ which, consistent with previous studies, resulted in the company disclosing more CSR information as an attempt to recovery legitimacy. Due to this fact we accept 
hypothesis H2. In our study the size of the company did not have a significant result regarding the level of CSR disclosure via Twitter, thus not making it possibly to verify hypothesis H1.

Regarding the control variables, the level of adherence by the CSR report to the 2016 GRI standards was found to be significantly and positively associated with CSR disclosure on Twitter, but neither CEODuality nor CSRComm were not significant to the model.

\section{Discussion}

Even though the percentage of tweets related to CSR is similar to that found in other studies regarding developed countries, our study suggests that the level of disclosure in the sample countries is still low, which implies that the companies do not disclose all of the topics about CSR. We found that human rights, responsibility and product labeling, were less disclosed than other categories. On the other hand, the companies disclose more information relating to the organizations profile, sustainability strategy, and community support. This reflects that, for companies in Latin America, CSR communication via Twitter is used as a legitimacy tool towards the surrounding community instead of a marketing tool to increase sales.

The results showed that companies which are active in the most highly polluting sectors present greater disclosure of CSR information on Twitter, which implies that this communication medium is used to enhance the firm's corporate image in the communities affected by its activities. This conclusion is reinforced by the descriptive results, which show that the Community category is the most frequently referred to in tweets, while mining, petroleum, and cement companies present the highest levels of disclosure. These findings are particularly significant in the Latin American context, since this region has experienced a large number of socio-environmental conflicts related to the increasing levels of extraction and exploitation of natural resources in recent years [28,82].

Regarding the characteristics of the CEO, it is clear that the tenure is one of features which most affect the level of CSR disclosure via Twitter. Taking into account that the CEO's outlook is usually transferred to the formulation of company strategies, it is reasonable to suppose that CEOs with greater tenure will seek to continue existing strategies, which they are familiar with and confident in their ability to manage. It may be asserted, therefore, that CEOs with less tenure present a longer time horizon and will experience greater pressure to demonstrate that they are capable of adapting to change, and that they will respond much more openly to the organisation's various stakeholders [83], at the same time that they might perceive strategic possibilities regarding improved visibility and legitimacy growth in the long run thanks to SNS. In consequence, our study results suggest that CEOs who have held their position for a shorter period might be more receptive to innovative forms of CSR disclosure using Twitter as a means of communication, which would facilitate greater stakeholder engagement.

\section{Conclusions}

The ease of access offered by social networks has favoured its use as a vehicle for communicating CSR information to stakeholders. With this in mind, one of our main study goals was to analyse the levels of disclosure on Twitter of CSR-related information by companies located in Pacific Alliance countries, according to the categories stipulated in the 2016 GRI standards.

The synthetic index created revealed that the most popular category in this respect was Community, followed by Strategy, which indicates that these companies are using Twitter as a tool for greater engagement with their stakeholders. Analysis of the TDI showed that Colombian and Mexican companies have higher levels of CSR disclosure while Peruvian companies have the lowest levels of disclosure. Additionally, those operating in sensitive industries tend to disclose more information in this respect, and publish a larger amount of tweets regarding environmental issues than companies that are considered less risky to the environment, which corresponds with the legitimacy theory. Furthermore, our results made it evident that the companies in the sample hardly disclosed any information regarding responsibility and product labeling, which suggests that consumers are not the target of their disclosed information. 
A further study goal was to determine the characteristics of the firm and of its CEO that most strongly influence the level of CSR disclosure on Twitter. To do so, we conducted a multivariate regression analysis, taking as the dependent variable the level of disclosure reflected in the TDI. The variables of interest were company size; the sensitive nature of the business sector in which the company operates; and the CEO's gender, age, and tenure. Control variables were the dual CEO-board chair role, the existence of a CSR committee on the board, and the level of adherence to the GRI standards in the 2016 CSR report. The explanatory analysis performed led us to conclude that firms operating in a sensitive industry were positively associated with their level of CSR disclosure on Twitter. On the other hand, the regression analysis did not reveal any significant relationship between corporate size and the level of disclosure. Regarding the characteristics of the CEO, we observed an inverse relationship between the length of time the CEO had held the position and the level of CSR disclosure on Twitter. The study hypotheses about age and gender were not verified in our study.

This study makes several novel contributions to the literature on CSR: firstly, by analysing the voluntary disclosure of CSR-related information by new channels of communication, in response to calls by Merkl-Davis and Brennan [6], among others, for social media to be included as an external medium of communication that could favour accountability. The second major contribution made is the construction of a disclosure index based on objective categories extracted from the 2016 GRI standards, which enhances our understanding of the use of Twitter as a means of communicating CSR information and introduces new elements with which to analyse corporate transparency and stakeholder engagement. Thirdly, our study findings show that certain corporate characteristics of the CEO influence levels of disclosure on Twitter, which is an innovative means of communication for corporate relations. Finally, companies from Pacific Alliance countries are included in our analysis of CSR disclosure, a context that is a significant field of study, since this Latin American region experiences many socio-environmental conflicts involving extractive industries, whose stakeholders have ample potential for dialogue, being highly active users of social networks.

Our study findings suggest various interesting areas for future research. From the standpoint of accountability, it is important to examine other factors that might motivate a company to make use of new communication media to publish information on social and environmental matters. In addition, regarding the analysis of information disclosure, it would be useful to study the tone and format of CSR messages published on social networks to determine their orientation and to analyse the responses of stakeholders to the information disclosed via these media.

The study is not exempt of limitations. First, the results of our study are highly influenced by the particular context of the countries analysed, which can limit its extrapolation to other contexts. Additionally, the use of certain observable characteristics of the CEOs can limit the analysis of the results. This implies that studies that make a more in depth analysis of the influence of the psychological and social characteristics of the CEOs regarding CSR communication are required.

Author Contributions: Conceptualization, Y.M.S.-R., M.G.-V., and M.A.G.-B.; Formal analysis, Y.M.S.-R.; Methodology, Y.M.S.-R.; Project administration, M.G.-V. and M.A.G.-B.; Supervision, M.G.-V. and M.A.G.-B.; Validation, M.G.-V. and M.A.G.-B.; Visualization, Y.M.S.-R.; Writing—original draft-Y.M.S.-R.; Writing一review \& editing-M.G.-V. and M.A.G.-B.

Funding: This research was funded by Generalitat Valenciana AICO/2017/092 and by the research grant ASEPUC 2017.

Acknowledgments: The authors acknowledge financial support received from Generalitat Valenciana AICO/2017/092 and from Research Grant ASEPUC 2017.

Conflicts of Interest: The authors declare no conflict of interest. 


\section{Appendix Coding Criteria}

\begin{tabular}{|c|c|c|}
\hline Sub-Index & Category & Classification Criteria \\
\hline \multirow{6}{*}{ General disclosure } & Organisational profile & $\begin{array}{l}\text { Information on organisational characteristics: brands, products, } \\
\text { location of operations, types of customers, quantity of } \\
\text { products offered. }\end{array}$ \\
\hline & Strategy and analysis & $\begin{array}{l}\text { Information about the relevance of sustainability for the } \\
\text { organization; trends that may affect it; and the main events, } \\
\text { achievements, and failures in the period. }\end{array}$ \\
\hline & Ethics and integrity & $\begin{array}{l}\text { Explains the principles, values, norms, and ethical standards of } \\
\text { the organisation, together with complaints mechanisms. }\end{array}$ \\
\hline & $\begin{array}{l}\text { Government and } \\
\text { governance practices }\end{array}$ & $\begin{array}{l}\text { Issues related to the organisation's governance structure and the } \\
\text { role of the board in risk management and in preparing the } \\
\text { sustainability report. }\end{array}$ \\
\hline & $\begin{array}{l}\text { Relations with } \\
\text { stakeholders }\end{array}$ & $\begin{array}{l}\text { Explains how stakeholders may participate and the } \\
\text { identification of the organisation's stakeholders. }\end{array}$ \\
\hline & Reporting practices & $\begin{array}{l}\text { The report, its content and verification, and the reporting period } \\
\text { or cycle. }\end{array}$ \\
\hline \multirow{6}{*}{ Economic issues } & Economic performance & $\begin{array}{l}\text { Aspects of the direct economic value generated and distributed } \\
\text { to capital suppliers, employees, and government, and the } \\
\text { financial implications, risks, and opportunities arising from } \\
\text { climate change. }\end{array}$ \\
\hline & Presence in the market & $\begin{array}{l}\text { Information about the proportion of senior managers hired from } \\
\text { the local community. }\end{array}$ \\
\hline & Indirect economic impact & $\begin{array}{l}\text { How the economic development of poorer areas has been } \\
\text { promoted and what improvements have been achieved in the } \\
\text { social conditions. }\end{array}$ \\
\hline & Acquisition practices & $\begin{array}{l}\text { How the company supports suppliers that are local or owned by } \\
\text { women or vulnerable groups. The forms of dialogue used to } \\
\text { relate with suppliers and policies for the inclusion of } \\
\text { new suppliers. }\end{array}$ \\
\hline & Anticorruption practices & $\begin{array}{l}\text { Issues related with policies, procedures, and/or legal actions } \\
\text { related to the prevention of corruption. }\end{array}$ \\
\hline & Unfair trade & $\begin{array}{l}\text { The company's position on monopolistic practices and free } \\
\text { competition; related legal actions and the results obtained } \\
\text { from them. }\end{array}$ \\
\hline \multirow{7}{*}{ Environmental issues } & Materials & $\begin{array}{l}\text { The inputs, renewable or non-renewable, used to manufacture } \\
\text { or package the company's products; the type of materials used } \\
\text { the company's operations and the supplies that are recycled, } \\
\text { reused, and recovered. }\end{array}$ \\
\hline & Energy & $\begin{array}{l}\text { The organization's policies on energy consumption and their } \\
\text { impact on climate change. }\end{array}$ \\
\hline & Water & $\begin{array}{l}\text { Aspects of the company's operations related to the impact on } \\
\text { water, through extraction or consumption, by type of source or } \\
\text { by volume, and whether water is recycled or reused. }\end{array}$ \\
\hline & Biodiversity & $\begin{array}{l}\text { The prevention, management, or repair of damage to natural } \\
\text { habitats in proximity to the company's operations. The positive } \\
\text { or negative impact made on biodiversity of flora and fauna. }\end{array}$ \\
\hline & Emissions & $\begin{array}{l}\text { Information about the release of substances into the atmosphere, } \\
\text { such as greenhouse gases, their current intensity, and policies to } \\
\text { reduce such emissions. }\end{array}$ \\
\hline & Effluents and waste & $\begin{array}{l}\text { Water spills, and the generation, treatment, and elimination of } \\
\text { waste. Product spills. }\end{array}$ \\
\hline & $\begin{array}{c}\text { Environmental } \\
\text { evaluation of suppliers }\end{array}$ & $\begin{array}{l}\text { The environmental filters applied in the evaluation and selection } \\
\text { of new suppliers, with respect to possible negative } \\
\text { environmental impacts. }\end{array}$ \\
\hline
\end{tabular}




\begin{tabular}{|c|c|c|}
\hline Sub-Index & Category & Classification Criteria \\
\hline \multirow{7}{*}{ Employment issues } & Employment & $\begin{array}{l}\text { The company's approach to job creation, hiring, retention, and } \\
\text { related practices. }\end{array}$ \\
\hline & $\begin{array}{l}\text { Worker-company } \\
\text { relations }\end{array}$ & $\begin{array}{l}\text { On timely and satisfactory consultations with employees and } \\
\text { their representatives, and the communication of significant } \\
\text { operational changes. }\end{array}$ \\
\hline & $\begin{array}{l}\text { Health and safety in the } \\
\text { workplace }\end{array}$ & $\begin{array}{l}\text { Organisational practices to ensure health and safety in the } \\
\text { workplace, and measures to analyse and control potential risks } \\
\text { in this respect. Current measures to promote and protect health } \\
\text { and well-being. }\end{array}$ \\
\hline & Training and education & $\begin{array}{l}\text { Policies and programmes for training and improvement of } \\
\text { employee skills, and evaluations of performance and } \\
\text { professional development. Annual training provided (hours), } \\
\text { financial support, and time allocated to training. }\end{array}$ \\
\hline & $\begin{array}{l}\text { Diversity and equal } \\
\text { opportunities }\end{array}$ & $\begin{array}{l}\text { Opportunities for equality, and/or obstacles in this respect. The } \\
\text { gender balance of workers, salary levels, women's participation } \\
\text { in governance, basic salaries for women and men and for } \\
\text { minority or vulnerable groups. }\end{array}$ \\
\hline & Non discrimination & $\begin{array}{l}\text { Cases of discrimination and corrective actions taken. Measures } \\
\text { adopted to prevent discrimination. }\end{array}$ \\
\hline & $\begin{array}{l}\text { Freedom of association } \\
\text { and collective bargaining }\end{array}$ & $\begin{array}{l}\text { The measures taken to allow and guarantee freedom of } \\
\text { association, and operative conditions within the organisation or } \\
\text { among its suppliers that may endanger this right. }\end{array}$ \\
\hline \multirow{8}{*}{ Social issues } & Child labour & $\begin{array}{l}\text { The measures taken to contribute to the abolition of child labour, } \\
\text { and the organisation's operations, or those of its suppliers, } \\
\text { presenting significant risk in this respect. }\end{array}$ \\
\hline & Forced labour & $\begin{array}{l}\text { The measures taken to contribute to the abolition of forced } \\
\text { labour, and the organisation's operations, or those of its } \\
\text { suppliers, presenting significant risk in this respect. }\end{array}$ \\
\hline & Safety practices & $\begin{array}{l}\text { The conduct of the organisation's security personnel towards } \\
\text { third parties, effective training in human rights and respect for } \\
\text { indigenous peoples. }\end{array}$ \\
\hline & $\begin{array}{l}\text { Rights of indigenous } \\
\text { peoples }\end{array}$ & $\begin{array}{l}\text { How the organisation prevents the rights of indigenous peoples } \\
\text { from being infringed and how respect and consultation with } \\
\text { indigenous peoples is fostered in matters that affect them. }\end{array}$ \\
\hline & $\begin{array}{l}\text { Evaluation of human } \\
\text { rights }\end{array}$ & $\begin{array}{l}\text { The organisation's approach to preventing and mitigating } \\
\text { negative impacts on human rights, and to creating and } \\
\text { upholding agreements and contracts with human rights clauses. }\end{array}$ \\
\hline & Local communities & $\begin{array}{l}\text { How the community's needs and vulnerabilities are addressed, } \\
\text { how negative impacts are prevented and/or alleviated, how the } \\
\text { organisation relates directly to each group, what community } \\
\text { development programmes are supported, and how consultation } \\
\text { processes are carried out. }\end{array}$ \\
\hline & $\begin{array}{l}\text { Social evaluation of } \\
\text { suppliers }\end{array}$ & $\begin{array}{l}\text { The social evaluation of suppliers and their selection, noting any } \\
\text { negative social impacts in this respect and the measures taken to } \\
\text { correct them. }\end{array}$ \\
\hline & Public policy & $\begin{array}{l}\text { The organisation's participation in public policies and in } \\
\text { lobbying. }\end{array}$ \\
\hline
\end{tabular}




\begin{tabular}{|c|c|c|}
\hline Sub-Index & Category & Classification Criteria \\
\hline \multirow{4}{*}{ Product liability issues } & $\begin{array}{c}\text { Consumers' health and } \\
\text { safety }\end{array}$ & $\begin{array}{l}\text { The health impacts of the organisation's products and services. } \\
\text { Improvements in product development, R\&D, certification, } \\
\text { manufacturing, production/service, distribution and/or } \\
\text { elimination. }\end{array}$ \\
\hline & $\begin{array}{l}\text { Marketing and product } \\
\text { labelling }\end{array}$ & $\begin{array}{l}\text { The organisation's policies concerning responsible marketing, } \\
\text { and its reporting of the origin of its services or product } \\
\text { components. }\end{array}$ \\
\hline & Consumer privacy & $\begin{array}{l}\text { How the privacy of the clients' personal data is protected. } \\
\text { Acknowledgment of identified cases of leaks, thefts or loss of } \\
\text { data. }\end{array}$ \\
\hline & $\begin{array}{l}\text { Socioeconomic } \\
\text { compliance }\end{array}$ & $\begin{array}{l}\text { The organisation's compliance with laws and regulations in } \\
\text { social and economic matters. }\end{array}$ \\
\hline
\end{tabular}

\section{References}

1. Baue, B.; Murninghan, M. The Accountability Web. Weaving Corporate Accountability and Interactive Technology. J. Corp. Citizsh. 2011, 41, 27-49.

2. Sundstrom, B.; Levenshus, A.B. The art of engagement: Dialogic strategies on Twitter. J. Commun. Manag. 2017, 21, 17-33. [CrossRef]

3. Abitbol, A.; Lee, S.Y. Messages on CSR-dedicated Facebook pages: What works and what doesn't. Public Relat. Rev. 2017, 43, 796-808. [CrossRef]

4. Etter, M. Reasons for low levels of interactivity: (Non-) interactive CSR communication in twitter. Public Relat. Rev. 2013, 39, 606-608. [CrossRef]

5. Etter, M. Broadcasting, reacting, engaging-Three strategies for CSR communication in Twitter. J. Commun. Manag. 2014, 18, 322-342. [CrossRef]

6. Merkl-Davies, D.M.; Brennan, N.M. A theoretical framework of external accounting communication: Research perspectives, traditions, and theories. Account. Audit. Account. J. 2017, 30, 433-469. [CrossRef]

7. Dutot, V.; Lacalle Galvez, E.; Versailles, D.W. CSR communications strategies through social media and influence on e-reputation An exploratory study. Manag. Decis. 2016, 54, 363-389. [CrossRef]

8. Chae, B.; Park, E. Corporate Social Responsibility (CSR): A Survey of Topics and Trends Using Twitter Data and Topic Modeling. Sustainability 2018, 10, 2231. [CrossRef]

9. Mazzei, M.J.; Noble, D. Big data dreams: A framework for corporate strategy. Bus. Horiz. 2017, 60, 405-414. [CrossRef]

10. U Mass-Darmouth. The 2017 Fortune 500 Go Visual and Increase Use of Instagram, Snapchat, and YouTube. Available online: https:/ / www.umassd.edu/cmr/socialmediaresearch/2017fortune500/\#d.en. 963986 (accessed on 3 April 2018).

11. Painter-Morland, M.; Deslandes, G. Reconceptualizing CSR in the Media Industry as Relational Accountability. J. Bus. Ethics 2017, 143, 665-679. [CrossRef]

12. Hossain, M.; Reaz, M. The determinants and characteristics of voluntary disclosure by Indian banking companies. Corp. Soc. Responsib. Environ. Manag. 2007, 14, 274-288. [CrossRef]

13. Tan, A.; Benni, D.; Liani, W. Determinants of Corporate Social Responsibility Disclosure and Investor Reaction. Int. J. Econ. Financ. Issues 2016, 6, 11-17.

14. Thijssens, T.; Bollen, L.; Hassink, H. Secondary Stakeholder Influence on CSR Disclosure: An Application of Stakeholder Salience Theory. J. Bus. Ethics 2015, 132, 873-891. [CrossRef]

15. Patten, D.M. Exposure, legitimacy, and social disclosure. J. Account. Public Policy 1991, 10, 297-308. [CrossRef]

16. Bakhtina, K.; Goudriaan, J.W. CSR reporting in multinational energy companies. Transf. Eur. Rev. Labour Res. 2011, 17, 95-99. [CrossRef]

17. Castelló, I.; Etter, M.; Årup Nielsen, F. Strategies of Legitimacy Through Social Media: The Networked Strategy. J. Manag. Stud. 2016, 53, 402-432. [CrossRef]

18. Bonsón, E.; Ratkai, M. A set of metrics to assess stakeholder engagement and social legitimacy on a corporate Facebook. Online Inf. Rev. 2013, 37, 787-803. [CrossRef] 
19. Cho, M.; Furey, L.D.; Mohr, T. Communicating Corporate Social Responsibility on Social Media: Strategies, Stakeholders, and Public Engagement on Corporate Facebook. Bus. Prof. Commun. Q. 2017, 80, 52-69. [CrossRef]

20. Li, Q.; Wei, W.; Xiong, N.; Feng, D.; Ye, X.; Jiang, Y. Social Media Research, Human Behavior, and Sustainable Society. Sustainability 2017, 9, 384. [CrossRef]

21. OECD. Government at a Glance: Latin America and the Caribbean 2017; OECD: París, France, 2016; ISBN 9789264266391.

22. Evans, M. 3 Things You Need To Know about Latin American Digital Consumers. Available online: https:/ / www.forbes.com/sites / michelleevans1/2017/08/10/3-things-you-need-to-know-aboutlatin-american-digital-consumers/2/\#6379015f226f (accessed on 12 June 2018).

23. Tench, R.; Jones, B. Social media: The Wild West of CSR communications. Soc. Responsib. J. 2015, 11, $290-305$. [CrossRef]

24. Kaplan, A.M.; Haenlein, M. Users of the world, unite! The challenges and opportunities of Social Media. Bus. Horiz. 2010, 53, 59-68. [CrossRef]

25. Jansen, B.J.; Zhang, M.; Sobel, K.; Chowdury, A. Twitter power: Tweets as electronic word of mouth. J. Am. Soc. Inf. Sci. Technol. 2009, 60, 2169-2188. [CrossRef]

26. Colleoni, E. CSR communication strategies for organizational legitimacy in social media. Corp. Commun. Int. J. 2013, 18, 228-248. [CrossRef]

27. Bachmann, P.; Ingenhoff, D. Legitimacy through CSR disclosures? The advantage outweighs the disadvantages. Public Relat. Rev. 2016, 42, 386-394. [CrossRef]

28. Benites-Lazaro, L.L.; Mello-Théry, N.A. CSR as a legitimatizing tool in carbon market: Evidence from Latin America's Clean Development Mechanism. J. Clean. Prod. 2017, 149, 218-226. [CrossRef]

29. Suchman, M. Managing Legitimacy: Strategic and Institutional Approaches. Acad. Manag. Rev. 1995, 20, 571-610. [CrossRef]

30. Freeman, R.E. Strategic Management: A Stakeholder Approach; Pitman: Mashfield, UK, 1984; Volume 1, ISBN 0631218602.

31. Zimmerman, M.A.; Zeitz, G.J. Beyond Survival: Achieving New Venture Growth by Building Legitimacy. Acad. Manag. Rev. 2002, 27, 414-431. [CrossRef]

32. Dowling, J.; Pfeffer, J. Organizational Legitimacy: Social Values and Organizational Behavior between the Organizations seek to establish congruence. Pac. Sociol. Rev. 1975, 18, 122-136. [CrossRef]

33. Cowen, S.S.; Ferreri, L.B.; Parker, L.D. The impact of corporate characteristics on social responsibility disclosure: A typology and frequency-based analysis. Account. Organ. Soc. 1987, 12, 111-122. [CrossRef]

34. Branco, M.; Rodrigues, L. Factors Influencing Social Responsibility Disclosure by Portuguese Companies. J. Bus. Ethics 2008, 83, 685-701. [CrossRef]

35. Bayoud, N.S.; Kavanagh, M. Factors Influencing levels of Corporate Social Responsibility Disclosure by Libyan Firms: A Mixed Study. Int. J. Econ. Financ. 2012, 4, 13-29. [CrossRef]

36. Gamerschlag, R.; Möller, K.; Verbeeten, F. Determinants of voluntary CSR disclosure: Empirical evidence from Germany. Rev. Manag. Sci. 2011, 5, 233-262. [CrossRef]

37. Du, S.; Vieira, E.T. Striving for Legitimacy Through Corporate Social Responsibility: Insights from Oil Companies. J. Bus. Ethics 2012, 110, 413-427. [CrossRef]

38. Hackston, D.; Milne, M.J. Some determinants of social and environmental disclosures in New Zealand companies. Account. Audit. Account. J. 1996, 9, 77-108. [CrossRef]

39. Wang, J.; Yao, S. The Determinants of Corporate Social Responsibility Disclosure: Evidence From China. J. Appl. Bus. Res. 2013, 29, 1833. [CrossRef]

40. Astley, W.; Van de Ven, A. Central Perspectives and Debates in Organization Theory. Adm. Sci. Q. 1983, 28, 245-273. [CrossRef]

41. Carpenter, M.A.; Geletkanycz, M.A.; Sanders, W.G. Upper Echelons Research Revisited: Antecedents, Elements, and Consequences of Top Management Team Composition. J. Manag. 2004, 30, 749-778. [CrossRef]

42. Hambrick, D.C.; Mason, P.A. Upper Echelons: The Organization as a Reflection of Its Top Managers. Source Acad. Manag. Rev. 1984, 9, 193-206. [CrossRef]

43. Ng, E.S.; Sears, G.J. CEO Leadership Styles and the Implementation of Organizational Diversity Practices: Moderating Effects of Social Values and Age. J. Bus. Ethics 2012, 105, 41-52. [CrossRef]

44. Hambrick, D.C. Upper Echelons Theory: An Update. Acad. Manag. Rev. 2007, 32, 334-343. [CrossRef] 
45. Petrenko, O.; Aime, F.; Ridge, J.; Hill, A. Corporate Social Responibility or CEO narcissism? CSR motivations and organizational performance. Strateg. Manag. J. 2016, 37, 262-279. [CrossRef]

46. Lewis, B.; Walls, J.; Dowell, G. Difference in Degrees: CEO characteristics and firm environmental disclosure. Strateg. Manag. J. 2014, 35, 712-722. [CrossRef]

47. Marais, M. CEO rhetorical strategies for corporate social responsibility (CSR). Soc. Bus. Rev. 2012, 7, $223-243$. [CrossRef]

48. Oh, W.-Y.; Chang, Y.K.; Cheng, Z. When CEO Career Horizon Problems Matter for Corporate Social Responsibility: The Moderating Roles of Industry-Level Discretion and Blockholder Ownership. J. Bus. Ethics 2016, 133, 279-291. [CrossRef]

49. Manner, M. The impact of CEO characteristics on Corporate Social Performance. Corp. Soc. Responsib. Environ. Manag. 2010, 93, 53-72. [CrossRef]

50. Khlif, H.; Achek, I. Gender in accounting research: A review. Manag. Audit. J. 2017, 32, 627-655. [CrossRef]

51. Huang, S.K. The Impact of CEO Characteristics on Corporate Sustainable Development. Corp. Soc. Responsib. Environ. Manag. 2013, 20, 234-244. [CrossRef]

52. Zhang, H.; Ou, A.Y.; Tsui, A.S.; Wang, H. CEO humility, narcissism and firm innovation: A paradox perspective on CEO traits. Leadersh. Q. 2017, 28, 585-604. [CrossRef]

53. Damanpour, F.; Schneider, M. Characteristics of innovation and innovation adoption in public organizations: Assessing the role of managers. J. Public Adm. Res. Theory 2009, 19, 495-522. [CrossRef]

54. Barker, V.L.; Mueller, G.C. CEO Characteristics and Firm R\&D Spending. Manag. Sci. 2002, 48, 782-801. [CrossRef]

55. Kitchell, S. CEO characteristics and technological innovativeness: A Canadian perspective. Can. J. Adm. Sci. 1997, 14, 111-121. [CrossRef]

56. Musteen, M.; Barker, V.L.; Baeten, V.L. The influence of CEO tenure and attitude toward change on organizational approaches to innovation. J. Appl. Behav. Sci. 2010, 46, 360-387. [CrossRef]

57. Finkelstein, S.; Hambrick, D.; Canella, A. Strategic Leadership: Theory and Research on Executives, Top Management Teams, and Boards; Oxford University Press: Oxford, UK, 2009; ISBN 978-0-19-516207-3.

58. Fuchs, C.; Hofkirchner, W.; Schafranek, M.; Raffl, C.; Sandoval, M.; Bichler, R. Theoretical Foundations of the Web: Cognition, Communication, and Co-Operation. Towards an Understanding of Web 1.0, 2.0, 3.0. Future Internet 2010, 2, 41-59. [CrossRef]

59. Lin, K.-Y.; Lu, H.-P. Why people use social networking sites: An empirical study integrating network externalities and motivation theory. Comput. Hum. Behav. 2011, 27, 1152-1161. [CrossRef]

60. Millham, M.H.; Atkin, D. Managing the virtual boundaries: Online social networks, disclosure, and privacy behaviors. New Media Soc. 2016, 20, 50-67. [CrossRef]

61. Telefónica Redes Sociales en el Mundo Corporativo. Experiencias y Aprendizajes. Available online: https: / / www.fundacioncarolina.es / wp-content/uploads/2015/07/Redes-sociales-mundo-corporativoDouglas-Ochoa.pdf (accessed on 12 April 2018).

62. Internet Live Stats Twitter Usage Statistics. Available online: http://www.internetlivestats.com/twitterstatistics/ (accessed on 4 April 2018).

63. Statista.com. Number of Monthly Active Twitter Users Worldwide from 1st Quarter 2010 to 4th Quarter 2017 (in Millions). Available online: https:/ / www.statista.com/statistics/282087/number-of-monthly-activetwitter-users/ (accessed on 4 April 2018).

64. Busch, T.; Shepherd, T. Doing well by doing good? Normative tensions underlying Twitter's corporate social responsibility ethos. Converg. Int. J. Res. New Media Technol. 2014, 20, 293-315. [CrossRef]

65. Van Dijck, J. Tracing Twitter: The Rise of a Microblogging platform. Int. J. Media Cult. Polit. 2012, 7, 333-348. [CrossRef]

66. Khalil, S.; O'sullivan, P. Corporate social responsibility: Internet social and environmental reporting by banks. Meditari Account. Res. 2017, 25, 414-446. [CrossRef]

67. Lyon, T.P.; Montgomery, A.W. Tweetjacked: The Impact of Social Media on Corporate Greenwash. J. Bus. Ethics 2013, 118, 747-757. [CrossRef]

68. Saxton, G.D.; Waters, R.D. What do Stakeholders Like on Facebook? Examining Public Reactions to Nonprofit Organizations' Informational, Promotional, and Community-Building Messages. J. Public Relat. Res. 2014, 26, 280-299. [CrossRef] 
69. Araujo, T.; Kollat, J. Communicating effectively about CSR on Twitter: The power of engaging strategies and storytelling elements For Authors Communicating effectively about CSR on Twitter The power of engaging strategies and storytelling elements. Internet Res. 2018, 28, 419-431. [CrossRef]

70. MERCO. Qué es Merco-Monitor Empresarial de Reputación Corporativa. Available online: http:/ / www. merco.info/co/que-es-merco (accessed on 11 July 2018).

71. Cegarra-Navarro, J.; Martínez-Martínez, A. Linking orporate social responsibility with admiration through organizational outcomes. Soc. Responsib. J. 2009, 5, 499-511. [CrossRef]

72. Ros-Diego, V.-J.; Castelló-Martínez, A.; Martínez-Arcos, C.-A. CSR communication through online social media. Rev. Lat. Comun. Soc. 2012, 67, 47-67. [CrossRef]

73. Odriozola, M.D.; Baraibar-Diez, E. Is Corporate Reputation Associated with Quality of CSR Reporting? Evidence from Spain. Corp. Soc. Responsib. Environ. Manag. 2017, 24, 121-132. [CrossRef]

74. Global Reporting Initiative. GRI Sustainability Reporting Standards. Available online: https://www. globalreporting.org/standards / (accessed on 12 February 2018).

75. Krippendorff, K. Content Analysis: An Introduction to Its Methodology; SAGE Publications: Thousand Oaks, CA, USA, 2012.

76. Conde, M.D.F.T. Diseño de Índices de Divulgación de la Información de Responsabilidad Social Empresarial y Gobierno Corporativo: Un Análisis en las Mayores Empresas de la Península Ibérica. 2014. Available online: http:/ / dehesa.unex.es / bitstream/handle/10662/2467 /TDUEX_2014_Conde_MF.pdf?sequence=1 (accessed on 12 February 2018).

77. Correa, T.; Hinsley, A.W.; Gil De Zúñiga, H. Who interacts on the Web? The intersection of users' personality and social media use. Comput. Hum. Behav. 2010, 26, 247-253. [CrossRef]

78. Wamba, F.; Carter, L.S. Twitter adoption and use by SMEs: An empirical study. In Proceedings of the 46 Hawaii International Conferences on System Sciences (HICSS), Maui, HI, USA, 7-10 January 2013.

79. Brammer, S.; Millington, A.I. Firm size, organizational visibility and corporate philanthropy: An empirical analysis. J. Bus. Ethics 2006, 15, 6-19. [CrossRef]

80. El Mercurio April 2016. Available online: http://www.emol.com/noticias/Nacional/2016/04/23/799468/ Girardi-anuncia-acciones-penales-contra-Codelco-por-grave-contaminacion-en-Chacabuco.html (accessed on 13 July 2018).

81. Cooperativa August 2016. Available online: https://www.cooperativa.cl/noticias/pais/medioambiente/ contaminacion/codelco-provoco-nuevo-derrame-de-concentrado-de-cobre-en-los-andes /2016-08-24/ 163051.html (accessed on 13 July 2018).

82. Pozas, M.D.C.S.; Lindsay, N.M.; du Monceau, M.I. Corporate social responsibility and extractives industries in Latin America and the Caribbean: Perspectives from the ground. Extr. Ind. Soc. 2015, 2, 93-103. [CrossRef]

83. Weng, D.H.; Lin, Z.; Amason, A.; Croson, R.; Dess, G.; Jargowsky, P.; Lim, E.; Peng, M. Beyond CEO Tenure: The Effect of CEO Newness on Strategic Changes. J. Manag. 2014, 40, 2009-2032. [CrossRef] 